Supplement of Nat. Hazards Earth Syst. Sci., 20, 2609-2626, 2020

https://doi.org/10.5194/nhess-20-2609-2020-supplement

(c) Author(s) 2020. This work is distributed under

the Creative Commons Attribution 4.0 License.

(c) (1)

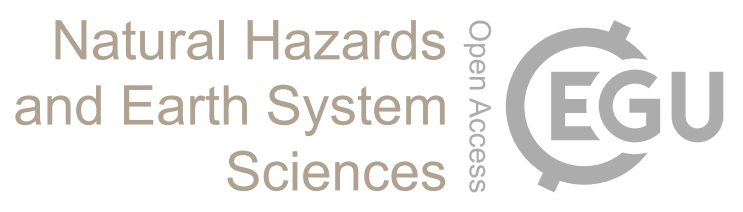

Supplement of

\title{
Quantifying processes contributing to marine hazards to inform coastal climate resilience assessments, demonstrated for the Caribbean Sea
}

Svetlana Jevrejeva et al.

Correspondence to: Svetlana Jevrejeva (svetlana.jevrejeva@gmail.com)

The copyright of individual parts of the supplement might differ from the CC BY 4.0 License. 


\section{Supplementary Tables}

Table S1: Saffir-Simpson Hurricane Scale (from US National Hurricane Center, https://www.nhc.noaa.gov/aboutsshws.php)

\begin{tabular}{|c|c|c|}
\hline Category & $\begin{array}{l}\text { Wind- } \\
\text { speed } \\
\text { range } \\
(\mathrm{m} / \mathrm{s})\end{array}$ & Likely Damage \\
\hline $\mathbf{1}$ & $33-42$ & $\begin{array}{l}\text { Very dangerous winds will produce some damage: Well-constructed frame homes } \\
\text { could have damage to roof, shingles, vinyl siding and gutters. Large branches of trees } \\
\text { will snap and shallowly rooted trees may be toppled. Extensive damage to power } \\
\text { lines and poles likely will result in power outages that could last a few to several } \\
\text { days. }\end{array}$ \\
\hline 2 & $43-49$ & $\begin{array}{l}\text { Extremely dangerous winds will cause extensive damage: Well-constructed frame } \\
\text { homes could sustain major roof and siding damage. Many shallowly rooted trees will } \\
\text { be snapped or uprooted and block numerous roads. Near-total power loss is expected } \\
\text { with outages that could last from several days to weeks. }\end{array}$ \\
\hline 3 & $49-58$ & $\begin{array}{l}\text { Devastating damage will occur: Well-built framed homes may incur major damage } \\
\text { or removal of roof decking and gable ends. Many trees will be snapped or uprooted, } \\
\text { blocking numerous roads. Electricity and water will be unavailable for several days } \\
\text { to weeks after the storm passes. }\end{array}$ \\
\hline 4 & $58-70$ & $\begin{array}{l}\text { Catastrophic damage will occur: Well-built framed homes can sustain severe } \\
\text { damage with loss of most of the roof structure and/or some exterior walls. Most trees } \\
\text { will be snapped or uprooted and power poles downed. Fallen trees and power poles } \\
\text { will isolate residential areas. Power outages will last weeks to possibly months. Most } \\
\text { of the area will be uninhabitable for weeks or months. }\end{array}$ \\
\hline 5 & $>70$ & $\begin{array}{l}\text { Catastrophic damage will occur: A high percentage of framed homes will be } \\
\text { destroyed, with total roof failure and wall collapse. Fallen trees and power poles will } \\
\text { isolate residential areas. Power outages will last for weeks to possibly months. Most } \\
\text { of the area will be uninhabitable for weeks or months. }\end{array}$ \\
\hline
\end{tabular}

Table S2: Tabulate 12 Caribbean tide gauge stations identified in Fig. 1

\begin{tabular}{|l|l|l|l|l|}
\hline Site & Name & Country & Longitude & Latitude \\
\hline SAC & San Andrés & Colombia & $81.701 \mathrm{~W}$ & $12.569 \mathrm{~N}$ \\
\hline LCR & Limon & Costa Rica & $83.020 \mathrm{~W}$ & $9.989 \mathrm{~N}$ \\
\hline CP & Cristobal & Panama & $79.915 \mathrm{~W}$ & $9.355 \mathrm{~N}$ \\
\hline CC & Cartagena & Colombia & $75.537 \mathrm{~W}$ & $10.391 \mathrm{~N}$ \\
\hline BBC & Bullen Bay & Curaçao & $69.020 \mathrm{~W}$ & $12.187 \mathrm{~N}$ \\
\hline
\end{tabular}




\begin{tabular}{|l|l|l|l|l|}
\hline PBG & Prickly Bay & Grenada & $61.765 \mathrm{~W}$ & $12.005 \mathrm{~N}$ \\
\hline FFM & Fort-de-France & Martinique & $61.063 \mathrm{~W}$ & $14.602 \mathrm{~N}$ \\
\hline PPG & Pointe à Pitre & Guadeloupe & $61.531 \mathrm{~W}$ & $16.224 \mathrm{~N}$ \\
\hline CAV & Charlotte-Amalie & US Virgin Islands & $64.92 \mathrm{~W}$ & $18.335 \mathrm{~N}$ \\
\hline MGPR & Magueyes Island & Puerto Rico & $67.046 \mathrm{~W}$ & $17.970 \mathrm{~N}$ \\
\hline MIPR & Mona Island & Puerto Rico & $67.938 \mathrm{~W}$ & $18.09 \mathrm{~N}$ \\
\hline PCDR & Punta Cana & $\begin{array}{l}\text { Dominican } \\
\text { Republic }\end{array}$ & $68.376 \mathrm{~W}$ & $18.505 \mathrm{~N}$ \\
\hline
\end{tabular}

Table S3: Wave model hindcast validation for climatology: Location of 7 wave buoys (Fig. 1), and summary statistics. NRecs $=$ number of records used for these calculations. PBias $=$ percentage bias, $\mathrm{mse}=$ mean squared error, $\mathrm{R}^{2}=$ correlation coefficient

\begin{tabular}{|l|l|l|l|l|l|l|l|}
\hline Buoy & Longitude & Latitude & time period & NRecs & PBias (\%) & mse (m) & $\mathbf{R}^{\mathbf{2}}$ \\
\hline 41043 & $64.830 \mathrm{~W}$ & $21.124 \mathrm{~N}$ & $2007-2016$ & 60,113 & +2.85 & 0.09 & 0.87 \\
\hline 41044 & $58.630 \mathrm{~W}$ & $21.582 \mathrm{~N}$ & $2009-2016$ & 56,715 & -0.85 & 0.10 & 0.86 \\
\hline 42056 & $84.946 \mathrm{~W}$ & $19.812 \mathrm{~N}$ & $2005-2016$ & 55,799 & +12.69 & 0.08 & 0.85 \\
\hline 42057 & $81.422 \mathrm{~W}$ & $16.908 \mathrm{~N}$ & $\begin{array}{l}2005-2016 \\
(\text { missing } 2007)\end{array}$ & 58,932 & +22.47 & 0.11 & 0.82 \\
\hline 42058 & $74.560 \mathrm{~W}$ & $14.775 \mathrm{~N}$ & $\begin{array}{l}2005-2016 \\
(\operatorname{missing} 2010)\end{array}$ & 36,514 & +5.82 & 0.10 & 0.87 \\
\hline 42059 & $67.483 \mathrm{~W}$ & $15.252 \mathrm{~N}$ & $2007-2016$ & 47,659 & +10.53 & 0.08 & 0.83 \\
\hline 42060 & $63.354 \mathrm{~W}$ & $16.413 \mathrm{~N}$ & $2009-2016$ & 58,140 & +3.92 & 0.06 & 0.82 \\
\hline All & & & & 318,073 & +6.18 & 0.119 & 0.85 \\
\hline
\end{tabular}

Table S4: Summary statistics of the WW3 Caribbean model validation for Oct-Nov 2010

\begin{tabular}{|l|c|c|c|}
\hline Buoy & Bias & Root Mean Square Error (m) & Correlation Coefficient \\
\hline 41043 & -0.06757 & 0.28 & 0.93 \\
\hline 41044 & -0.05159 & 0.25 & 0.92 \\
\hline 42056 & -0.1075 & 0.24 & 0.90 \\
\hline 42059 & -0.1142 & 0.32 & 0.91 \\
\hline 42060 & -0.1306 & 0.27 & 0.91 \\
\hline
\end{tabular}

Supplementary Figures 


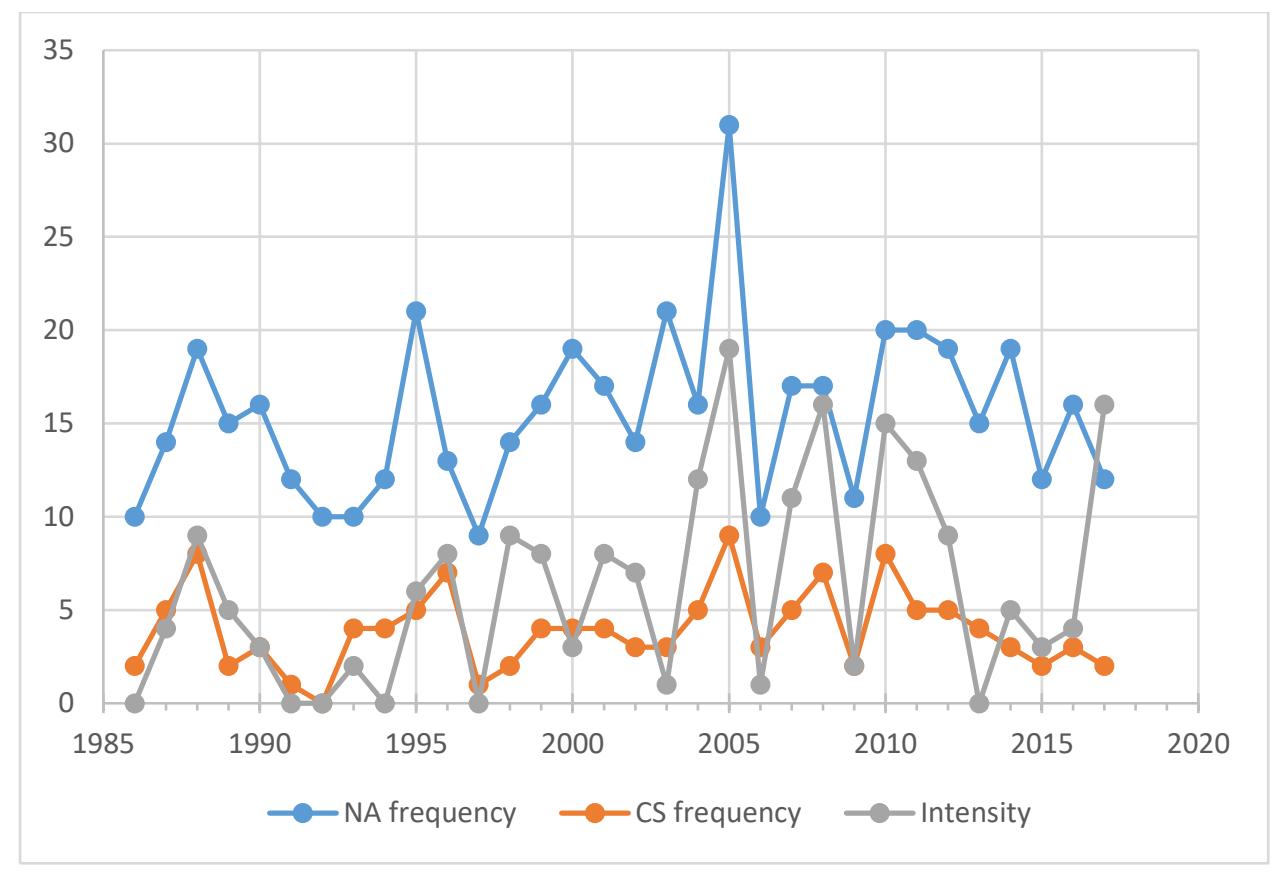

Figure SI1: Frequency of occurrence (number per year) of tropical cyclones in the North Atlantic (NA) and Caribbean Sea (CS) during 1986-2017 plus a metric of intensity of the storms occurring in the Caribbean.

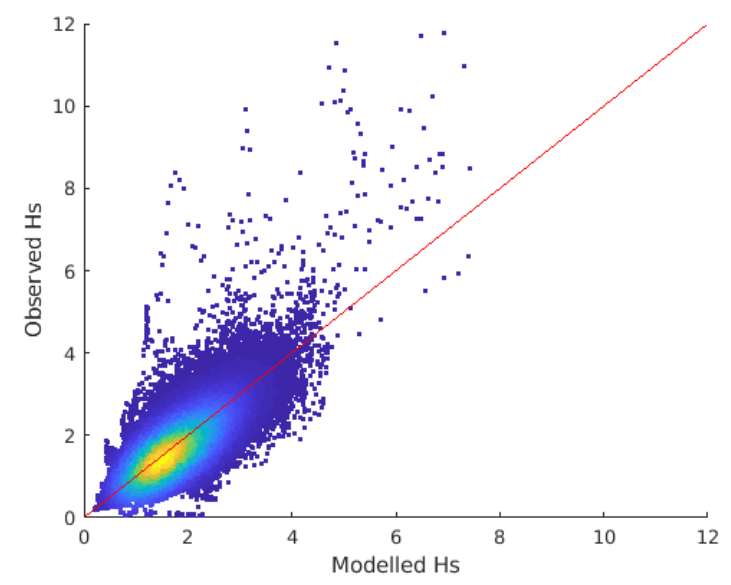

Figure S2: Density scatter plot comparing modelled and observed $H_{S}(\mathrm{~m})$ for 318,073 values across all buoys. A 1:1 correlation line shown in red. 


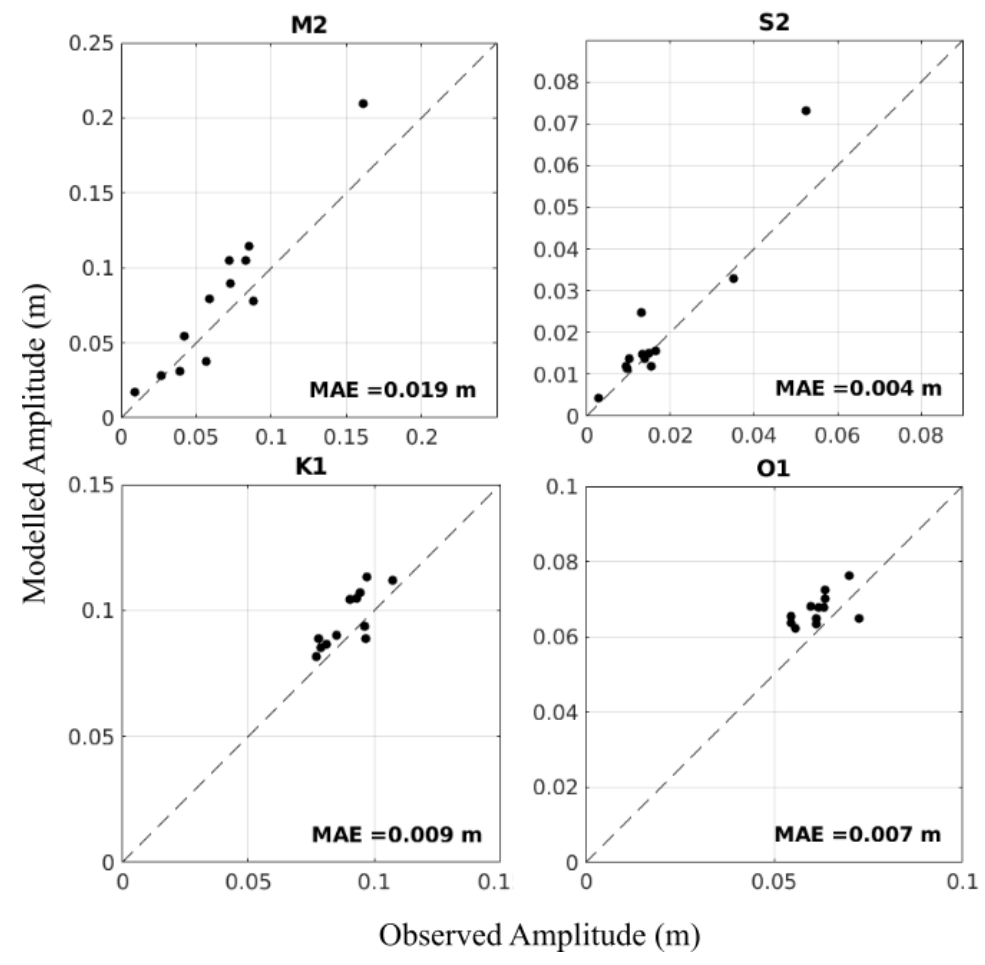

Figure S3: Modelled amplitudes vs. observed amplitudes for four constituents at 12 tide gauge locations. The Mean Average Error (MAE) is also shown. Dashed line shows y =x. All values are in metres.

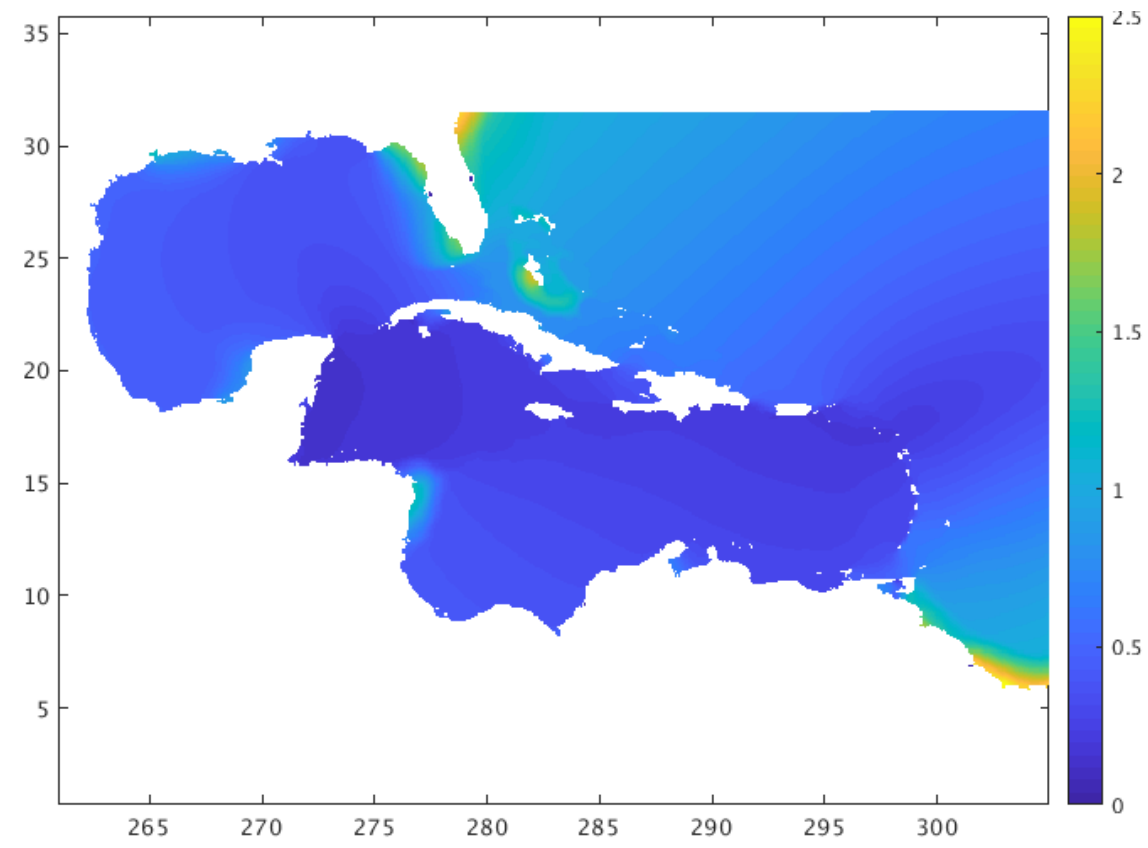

Figure S4: Great diurnal tidal range from NEMO. 


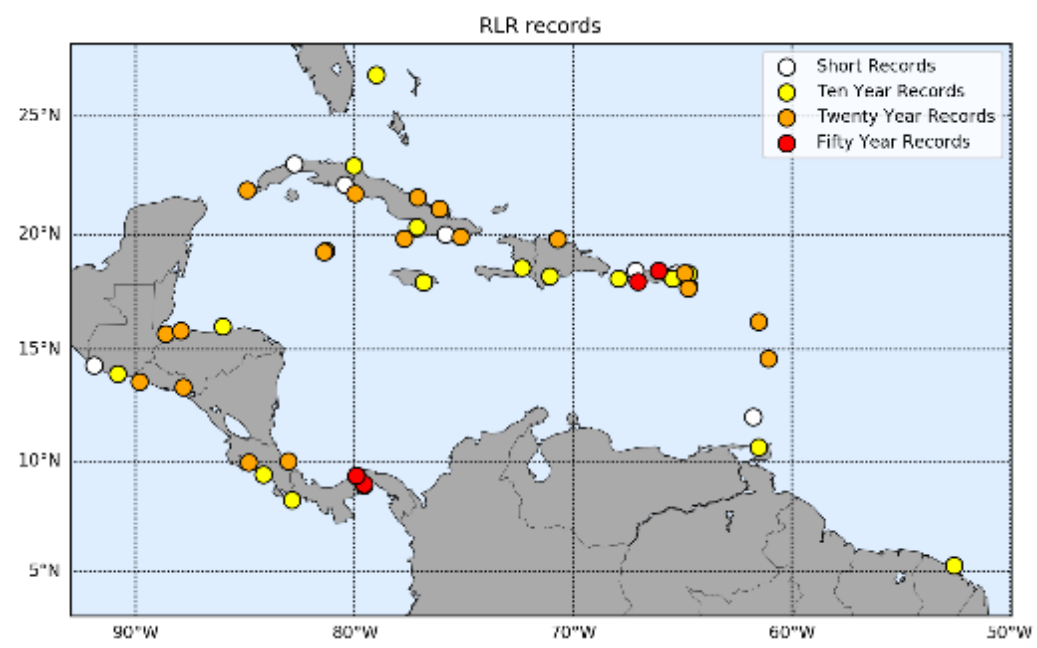

Figure S5: Locations of tide gauge records (historical monthly mean sea level data with revised local reference (RLR)) available from the Permanent Service for Mean Sea Level (PSMSL).

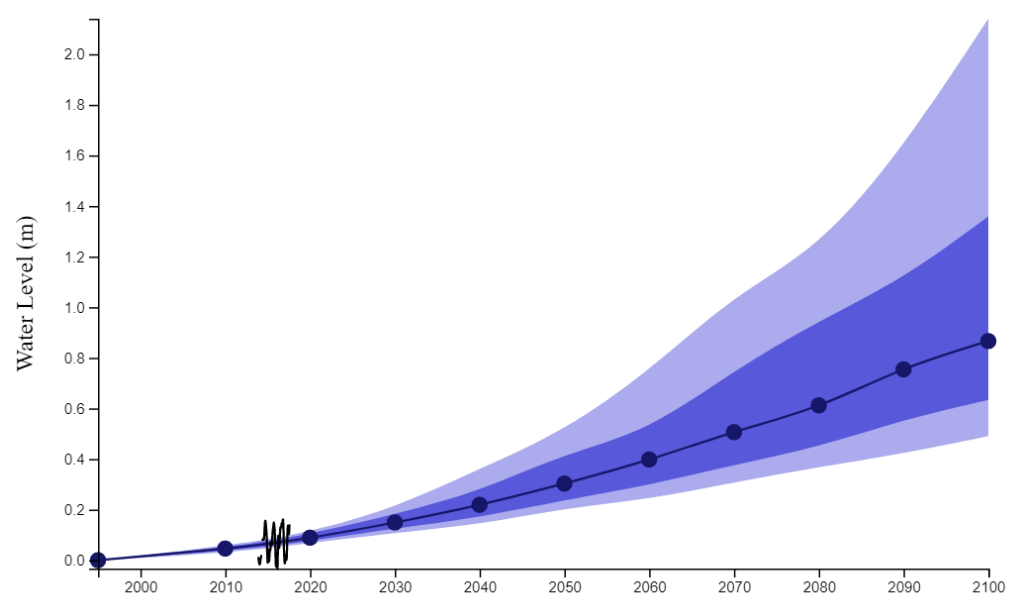

Figure S6: Observed (black, based on annual mean tide gauge data) and projected (thick blue line is representing the median and blue shadows are 17-83th and 5-95th percentile) sea level changes (m) in Saint Vincent and the Grenadines by 2100 , RCP 8.5 scenario.

\section{Supplementary text}

Recent hurricane impacts in the Caribbean Sea, especially Lesser Antilles:

There are only 9 explicit mentions of storm surge during the 32-year period (1986-2017) and 5 mentions of waves (from annual hurricane season entries in Wikipedia). 
1. Iris (Cat 2), Aug 1995: high waves in Trinidad caused coastal flooding and damage to boats.

2. Luis (Cat 4) Sep 1995: strong winds and high waves wreaked havoc on several islands in the Lesser Antilles; in Dominica, storm surge left 1,000 people homeless and \$47 million in property losses, destroying $90 \%$ of the banana crop.

3. Marilyn (Cat 3) Sep 1995: storm surge in the Charlotte Amalie harbour (USVI) beached the USCGC Point Ledge and damaged many smaller boats.

4. Iris (Cat 4), Oct 2001: landfall in Belize, produced 2.4-4.6 m storm surge.

5. Michelle (Cat 4), Nov 2001: landfall in south-central Cuba, causing 1.2-1.5 m waves, with a heavy storm surge. One of only 4 category 4 hurricanes in November.

6. Ike (Cat 4), Sep 2008: western areas of Cuba, major flooding from rain and storm surge, 7 deaths

7. Omar (Cat 4), Oct 2008: storm surge estimated at 0.61-1.22 $\mathrm{m}$ in Antigua and Barbuda with waves reaching 1.5-2.4 m; in Saint Croix (USVI), waves up to $4.6 \mathrm{~m}$ sank about 47 boats, causing oil spill. Storm surge in Saint Lucia.

8. Gonzalo (Cat 4), Oct 2014: high winds in Antigua and Barbuda, storm surge damaged boats

9. Earl (Cat 1), Aug 2016. Landfall in Belize, coastal and inland flooding, and a significant storm surge.

Figure SI1 shows the frequency of occurrence of all tropical storms in the North Atlantic (NA) and the Caribbean Sea (CS) respectively over the 30-year period. An average of about 16 tropical storms per year occur in the North Atlantic but only about 4 per year touch the Caribbean Sea (note that the category referred to for each storm is the maximum strength achieved over its lifetime, which may not have occurred while in the Caribbean Sea). A metric of the storm intensity for the season has been included, by summing up the CS storms reaching hurricane strength and multiplying by a weighting factor of 1 for a Category 1, 2 for a Category 2, etc., up to 5 for a Category 5 . There is no indication of a trend in frequency or intensity over this period, however there is considerable interannual variability. Only in 3 seasons in the last 30 years $(2005,2007$, and 2017) has more than one Category 5 hurricane formed. Only in 2005 have more than two Category 5 hurricanes formed, and only in 2007 and 2017 did more than one make landfall at Category 5 strength. 